\title{
Language Policy and Multilingualism in the City of Osijek in a Diachronic Perspective ${ }^{1}$
}

\author{
Dubravka Papa ${ }^{1}$, Željko Rišner $^{2}$ \\ ${ }^{1}$ Josip Juraj Strossmayer University in Osijek, Faculty of Law Osijek, Croatia \\ ${ }^{2}$ Josip Juraj Strossmayer University in Osijek, Faculty of Law Osijek, Croatia
}

\begin{abstract}
The city of Osijek (Croatia) has been for centuries a place of various contacts arising from direct or indirect social interactions of speakers reflecting their linguistic and non-linguistic (i.e. cultural, political and social) backgrounds. It has thus been the place of urban multilingual social inclusion and linguistic diversity. In this context, the paper aims at providing a theoretical and historical framework for language policy types that facilitated multilingualism in Osijek with reference to a particular German dialect of Osijek (Croatian: esekerski). The methodology applied in the paper is the primary sources analysis (applicable legislation, statistical demographic and historical data), interpretation of relevant LPP theories as well as a comparison regarding the language policy and languages spoken in the city of Osijek since the 19th century. In conclusion, the authors determine the role of language policy in maintaining the multilingual feature of the city of Osijek and give recommendations therefor.
\end{abstract}

Keywords: esekerski; linguistic contact; linguistic interaction; LPP; multilingual inclusion

\section{Introduction}

Language policy in multilingual environments has usually been subject to diachronic scholarly analyses. The historical overview of language policies and linguistic diversity provides insight into linguistic practices of the speakers of a particular language and a valuable basis for drawing conclusions on language vitality and visibility. In this regard, a number of Croatian and international authors have been dealing with different aspects of language policy and language planning in Croatia, but only a few with language policy in the city of Osijek. However, the topics of multilingualism and language policy and planning (hereinafter: LPP), as frequent and challenging topics of the European Union policies, have increasingly become the subject of interest not only among Croatian sociolinguists but among other branches (e.g. jurists and social scientists) as well, raising the approach to this topic to an interdisciplinary level. Thus, the purpose of this paper is to provide a theoretical and historical framework for language policy types that facilitated multilingualism in the city of

\footnotetext{
${ }^{1}$ This paper is an output of work that has been fully supported by the Faculty of Law Osijek, Josip Juraj Strossmayer University of Osijek under the project nr. IP-PRAVOS-20 "Nijemci i Austrijanci i njemački jezik i kultura u gradu Osijeku kroz povijest - pravni i lingvistički aspekti“ [Germans and Austrians and the German language and culture in the city of Osijek throughout history - legal and linguistic aspects]
} 


\title{
8 International Conference on Research in
}

\section{BEHAVIORAL \& SOCIAL SCIENCES}

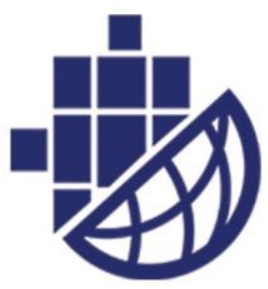

July $23-25,2021$

\author{
Stockholm, Sweden
}

Osijek based on the analyses of applicable legislation, statistical demographic and historical data in the archives as primary sources. The aim of this historical review of linguistic diversity and language policies in the city of Osijek is to make a brief overview of linguistic relations in the history of the city of Osijek with an emphasis on the 19th century language policies. It is important to note that the paper deals with the limited number of applicable laws and regulations of the time although the Austro-Hungarian Monarchy is known to have passed elaborate legislation. As regards language policy, the de facto and de jure language policies of the time were often quite inconsistent. Thus, Latin was the official language in the Croatian Parliament until 1848, when it was replaced by Croatian, but German was the de facto official language of the empire (Rindler Shjerve in Sočanac 2012:300). The practice in this context often did not even come close to the official regulations passed by the Monarchy.

\subsection{Defining language policy}

When it comes to language policy and planning theory and definition, there is only one thing that scholars agree on, and that is a contradiction that language policy and language planning are closely related but still different activities. The relation and hierarchy between planning and policy have been topics of numerous discussions (e.g. Kaplan and Baldauf 1997, Schiffmann 1996). Most authors agree that the traditional term - language policy and planning (LPP) should be used since it implies both (un)intentional and (un)planned activities regarding language in a society (Johnson, D.C. 2013). In this paper, the authors adopt the term language policy for terminological simplicity referring to a set of laws or regulations and practices aimed at carrying out a planned language change in a system (Kaplan and Baldauf 1997). However, since according to Schiffman $(1996)^{2}$ language policy is a social/cultural construct it comprises various elements as speakers' input when dealing with a language from their background (linguistic culture-as the sum of ideas, beliefs, attitudes, and values).

\subsection{Defining multilingualism}

We speak of multilingualism as a specific case of languages in contact "when a speaker or group can use several language systems, when two or more language systems are in contact in one speaker or a group of speakers" (Papa 2017:43 according to Škiljan 1980:141). Multilingualism refers to the use of two or more languages either willingly or by force and people have been trying to manage this phenomenon for centuries (even by imposing the language of the winners over the occupied territories or by introducing various LPP approaches). Romaine (2003:512) suggests that multilingualism exists within the cognitive systems of individuals, families, communities, and states, which requires the study of different aspects of the phenomenon by various subdisciplines (linguistics, psychology, sociology, and education). Linguistically a distinction is drawn between individual and societal multilingualism (ibid.). Riehl (2013) differentiates among three types of multilingualism: individual (plurilingualism), institutional and territorial multilingualism. The

\footnotetext{
${ }^{2}$ Schiffman (2003) introduced the terms: explicit and implicit language policies. Explicit language policies are top-down, public, official, de iure whereas implicit policies are unwritten, informal, de facto policies in practice.
} 


\section{$8^{\text {th }}$ International Conference on Research in}

\section{BEHAVIORAL \& SOCIAL SCIENCES}

July 23-25,2021

Stockholm, Sweden

paper deals with multilingualism as a societal phenomenon in the city of Osijek in the 19th century.

\section{Origins and features of multilingualism in the city of Osijek in the $19^{\text {th }}$ and $20^{\text {th }}$ centuries - the case of the Osijek German dialect}

The city of Osijek is situated in the region of Slavonia, eastern Croatia and has always been a place of multitude of contacts resulting in cultural, social and linguistic interactions among speakers of various languages. It has had a rich linguistic diversity that reflected in the list of the languages that were spoken in the area of Osijek in the course of its history such as Celtic, Latin, Hungarian, Turkish, German, Serbian, Croatian, some of which were official languages in this area at different points in the past. The abundance of languages (fig. 1) that existed in the Austro-Hungarian Monarchy reflected in the languages spoken in the city of Osijek, as well.

Figure 1: Austro-Hungarian Monarchy language areas

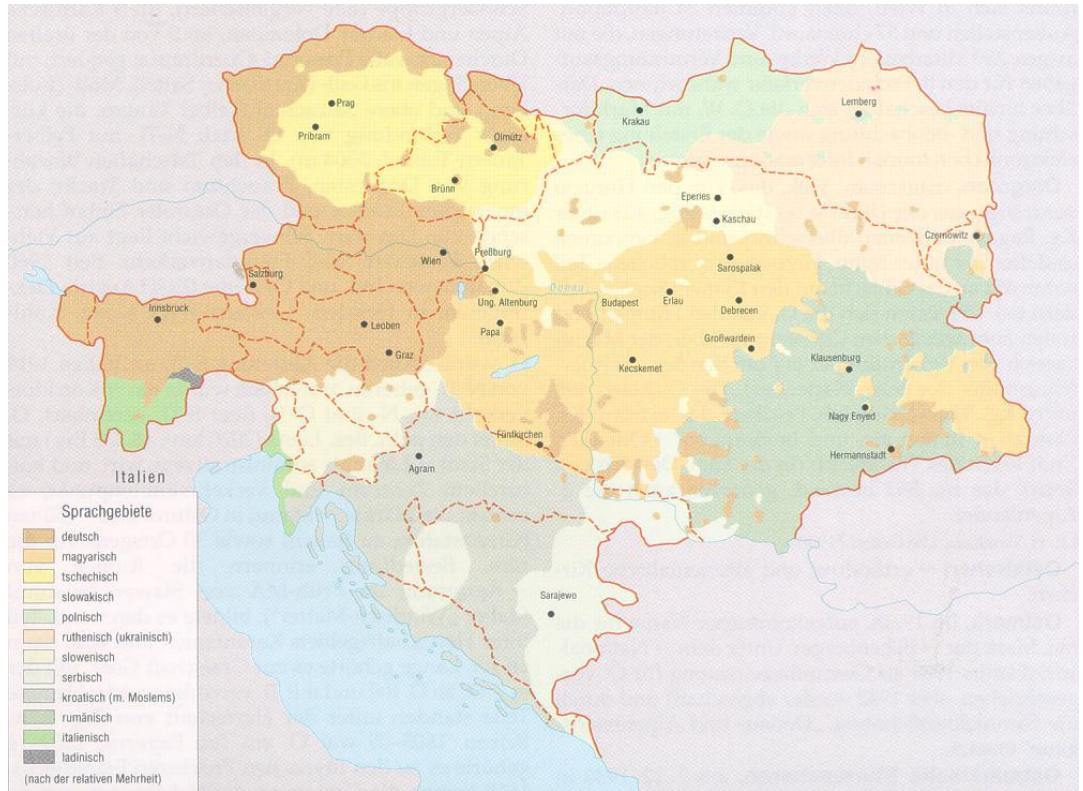

Source: (Copyright Verlag Ed. Hölzel, Vienna, for AEIOU) Downloaded from https://austriaforum.org/af/AEIOU/\%C3\%96sterreichisch-ungarische_Monarchie\%2C_Doppelmonarchie 


\section{International Conference on Research in}

\section{BEHAVIORAL \& SOCIAL SCIENCES}

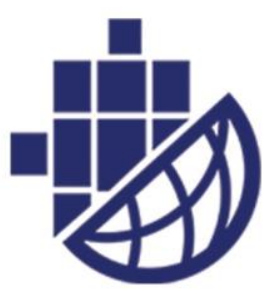

July $23-25,2021$

Stockholm, Sweden

\subsection{Esseker Deutsch - the Osijek German Dialect ${ }^{3}$}

\subsubsection{Historical background}

Osijek was throughout its long history defined by its specific geographic position on the right bank of the Drava river, at a point that allowed relatively easy crossing to the left bank of the river. This fact gave the town its Slavic name Osek/Osik/Osijek - indicating a place where the water level is low and the river can be crossed. The strategic importance of this location resulted in the rise and prosperity of various settlements from antiquity to modern times but also in their destruction in numerous wars that were fought in this part of Europe. The topic of this paper - the Esseker dialect - was born in the aftermath of the wars between Austria and the Ottoman Empire that ended with the liberation of Osijek 1687 (after 161 years of Turkish rule) and with the peace treaty signed in Srijemski Karlovci in 1699 by which all of Slavonia was liberated from the Turks. During the last two decades of the 17th century, especially after the Turks attacked Vienna in 1683, the war operations were intensified. As the Austrians started to push the Turks back east, the situation in Slavonia deteriorated and a large part of its population left the region. According to the 1696 census, the county of Osijek had only 8 populated villages and 313 villages were completely abandoned. The population of Slavonia came down to about 40,000 - barely $20 \%$ of the population before 1683 - turning the east of Croatia into a wasteland (Sršan, 2000).

\subsubsection{The New Beginning}

On the site of the ravaged Turkish town, Austrian authorities started building a fortress that was intended to protect the river crossing and keep the eastern Slavonian border safe against Turkish raids. After the treaty between Habsburg Empire and the Ottoman Empire was signed in Srijemski Karlovci in 1699, the military function of the Fortress of Essegg, as it was now called, became of secondary importance; the army command and a troop remained in it, but it also welcomed civilians of various professions from different parts of the Habsburg Empire. This was the core of the new multiethnic and multilingual community. The depopulated Slavonian land was given to mostly Austrian, German and Hungarian noble families as reward for military services. Land without people was useless, so these new landowners colonized people from their estates in other parts of the Empire into Slavonia and Syrmia. Swabians, Bavarians, Slovaks, Czechs, Ruthenians, Jews and others mixed with the remaining indigenous Croatian and Hungarian population and with Serbian immigrants who escaped the Turkish rule in their homeland. This colonization process resulted not only in the repopulation of abandoned villages but also in the establishment of new settlements in which the colonists from German lands assumed the leading role and kept it for a long time (Mažuran, 1993). The area around the Fortress (Croatian: Tvrđa) was no exception, so a settlement called Varoš or Podgrađe developed outside the walls and was later moved to the

\footnotetext{
${ }^{3}$ This urban dialect speaks for the multilingual feature of the urban area emerging beyond official language policy, in the sense of Weinreich's theory of language planning based on languages and dialects in interaction. The authors of the paper reason that the Esseker Deutsch emerged in a multilingual setting according to the social and linguistic necessity in a situation where multilingual community did not „keep their languages and dialects separate and produced instead a hybrid by blending the features of the available communication forms“" (Lo Bianco, 2010).
} 


\title{
8 International Conference on Research in
}

\section{BEHAVIORAL \& SOCIAL SCIENCES}

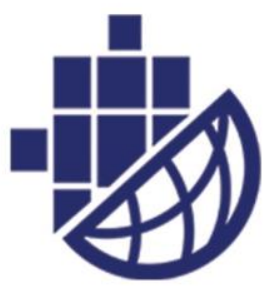

July $23-25,2021$

\author{
Stockholm, Sweden
}

west, thus forming the Upper Town (Gornji Grad) with Croatian, German, Austrian, Hungarian, Slovakian and Jewish population. To the east, there was the Lower Town (Donji Grad) with Croatian and German population and a large Serbian community. To the west from the Upper Town, the former village called Petrus was populated by Hungarian Protestants who renamed the village into Rétfalu, and by German Catholics, who named it Rieddorf - the village later received the Croatian version of its name - Retfala (Njari, 2010). Two villages with German colonists also developed on the left Drava bank - Klein Darda (Hungarian: Kísdarda; Croatian: Tvrđavica) to the north and northwest, and Dörfl (Hungarian: Jenőfalva; Croatian: Podravlje) north east from the Fortress. Finally, south of the Fortress there was another settlement named New Town (Novi Grad) with predominantly German population. The three town communities (Fortress - Tvrđa, Upper Town and Lower Town) were united into one - the town of Osijek, which was in 1809 given the status of a Free Royal Town. According to the data from 1814, the civilian population of Osijek reached almost 9,000, which made Osijek the largest town in Croatia (Sršan, 1996).

\subsubsection{The lingua franca of Osijek}

With the establishment of Austrian rule in Slavonia, German became the official language of administration. Although at that time German and Austrian immigrants did not yet make the majority of the population, German was the language understood by most of the people who colonized Slavonia. On the other hand, indigenous population had to learn German to be able to communicate with the authorities. German therefore provided a perfect foundation for communication within the growing multi-ethnic, multireligious and multilingual community (Bilić-Meštrić, 2014). Various backgrounds and great differences in education of the rapidly growing population strongly influenced the way in which the German foundation was used. The more educated population - clergy, teachers, tradespersons, merchants, officers, lawyers and physicians tended to use the standard German language, or its Austrian variant. However, since these people came from different parts of the German speaking areas, their spoken language also varied quite significantly (Petrović, 2011). The rest of the population, who were not native speakers of German, modified, adapted and complemented the language with Croatian, Serbian, Yiddish or Hungarian words and phrases. In the process of creation of the Esseker dialect, each of the previously mentioned 7 settlements (Fortress, Upper Town, Lower Town, New Town, Retfala, Tvrđavica and Podravlje) enriched the dialect with their own specific contributions. These contributions were specific mixtures of words from different German dialects with Croatian, Serbian and Hungarian words (Petrović, 2001). In time, this new common language became a part of the town's identity - it provided the bond that allowed Osijek's multi-ethnic community to function as one. Through Esseker dialect, the inhabitants of Osijek learned to tolerate and respect each other. It was their language; it characterized them as fellow-citizens and gave them a sense of belonging to this new homeland.

\subsubsection{Language Policy vs. Language Reality}

For Osijek, as for most of Croatia, the past two and a half centuries were characterized by numerous changes of political situation; it was part of several different states and each of these new "masters" introduced new laws, economic rules and priorities, and, of course, language policies. Throughout the 19th and in early 20th centuries they had little effect on the 


\title{
8 International Conference on Research in
}

\section{BEHAVIORAL \& SOCIAL SCIENCES}

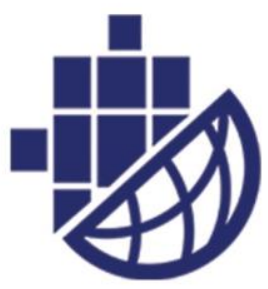

July $23-25,2021$

\author{
Stockholm, Sweden
}

Esseker dialect, which in these hundred years benefitted from the constant influx of people from different parts of Central Europe bringing fresh sets of words and information to Osijek. The town was rapidly developing into an industrial centre and this development was accompanied by a change in the structure of population. Instead of skilled artisans and educated professionals, the growing industry needed workers with no particular education. In the middle of the 19th century, they became the majority of the population speaking the Esseker dialect. As a primarily spoken language without a written form, it proved perfect for the lower strata of the society.

\subsubsection{The Esseker Dialect as a Symbol of Osijek's Multilingual Community}

Another interesting feature also made it attractive for the common people: since it did not follow the rules of any of the standard languages whose words it used but followed selected rules in word formation and syntax, the Esseker dialect gave its speakers a feeling of freedom. It could even be said that it defied the rules imposed by official language policy, especially in the 20th century between the two World Wars. After 1860, German was no longer the official language but the Esseker dialect stayed very much alive and was used by the majority of Osijek's population regardless of the official language defined by the politics.

In 1929, in Berlin's newspaper Neue Freie Presse, the famous Austrian author Alexander Roda Roda, who spent 7 years of his life in Osijek, wrote a review of the collection of short stories in the Esseker dialect collected and published by Lujo Plein. Roda Roda compared the Esseker dialect wit Pennsylvanian German (Pennsylvanischdeutsch) that had a similar history as the German dialect of Osijek (Petrović, 2011). However, at that time Pennsylvanian German was already dying overpowered by a much stronger and dominant English language. In the late 1920's, the end of the Esseker dialect was not yet in sight although it, too was slowly losing its foundations after the Serbo-Croatian had been introduced as the language of education in the Kingdom of Slovenes, Croats and Serbs, that Croatia became a part of after the Great War, and that later became the Kingdom of Yugoslavia.

\subsubsection{Some Characteristics of the Esseker Dialect}

The Esseker dialect was praised by some and criticised, even despised by others. Sometimes, people developed a love/hate relation towards the dialect: they criticized it as low, rude and primitive but the moment they left Osijek, even for a short period of time, they somehow missed this peculiar mixture. Wilma von Vukelich, a famous Osijek lady, wrote in her memoirs," (...) The Esseker German [...] was no language, but a hardly describable mixture of languages spoken between two tollbooths and understood only by those born and raised in the same area. In this idiom, final vowels, consonants and whole syllables are swallowed. There isn't a single clear sound (...). There is no sentence without foreign elements, and there is no sign of syntax, grammar or orthography. (...) There are also Serbian impurities imported by the Lower Town indigenous population, furthermore, there is the broken German and Croatian spoken by the officials at the nearby Military Frontier; there is also the poor style of local German newspapers and the false theatrical pathos of travelling actors' troops from Olomouc or Bratislava.(...)"

If one were to read only this part, the conclusion would be quite simple: Mrs. Vukelich was not very fond of the Esseker dialect! - But then she goes on saying," Down there, I have 


\section{International Conference on Research in}

\section{BEHAVIORAL \& SOCIAL SCIENCES}

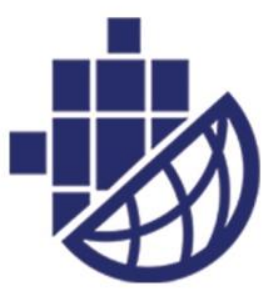

July $23-25,2021$

Stockholm, Sweden

learnt the most beautiful Esseker dialect that has forever remained in my ear and that I could not free myself from, despite my German governesses and my German classes with evangelical Pastor Pindor, who spoke Silesian - the purest German language in the whole Monarchy." (Vukelich, 1992)

\subsubsection{Some Linguistic Characteristics of the Esseker Dialect ${ }^{4}$}

The most significant feature of the Osijek Dialect is the fact that it is a spoken variety of language with no prescribed orthography. The first attempts to write it down and preserve it for future generations and maybe provide some material for linguistic studies were made by Lujo Plein between 1929 and 1938 (Plein, 2002). His five editions of collected short stories in the Esseker dialect were collected, analyzed and published in the 1990's and early 2000's by Velimir Petrović (Petrović, 2001). These texts were written down phonetically following Croatian orthography.

Pronunciation: words were generally pronounced following the German pronunciation rules. However, there were significant differences in pronunciation between different parts of town, and some differences were caused by different mother tongues of the speakers, different levels of education or even family background. In reality, every speaker of the Esseker dialect could sound a little different than the others (Petrović, 2011).

Vowels: - Long single vowels are sometimes used instead of diphthongs (e.g. [a:] instead

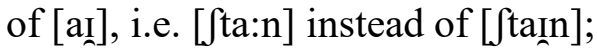

- [a] is "rounded up" and replaced with [å] - [fåta] instead of ['fa:te], with [ou] [moun] instead of [man] or [oa] - [Jtoak] instead of [Jtask]

- $\quad[\mathrm{o}]$ is frequently replaced with $[\mathrm{u}]-[\mathrm{khum}]$ instead of [kom]; etc.

Consonants: - there are three different types of $h$ : $[\mathrm{h}]$ at the beginning of a word or syllable before a vowel; [x] after a, o, u, au, ou; and [ç] after e, i, ai, aj, l, n, r;

- $\quad[\mathrm{k}]$ is frequently aspired before vowels

- $\quad[r]$ is less vibrating than in Croatian

- $\quad$ voiced consonants $[\mathrm{b}],[\mathrm{d}]$ and $[\mathrm{g}]$ at the beginning of a word are replaced by their voiceless pairs [p], [t] and [k]: [pruda] instead of ['bьu:de]; [tanke] instead of ['dankə]; [kuad] instead of [gu:t].

Diphtongs are used in some words instead of vowels with umlaut: [teafn] instead of

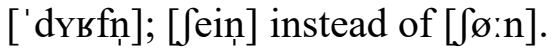

In other words with umlaut, ü is replaced by u or i: [fruštuk] / [frištik] instead of ['fьy: ,ftyk]; [zi:s] instead of [zy:s] and ö is replaced with e: [lefl(a)] instead of ['lœfl].

\footnotetext{
4 The description of some of the linguistic characteristics of the Esseker dialect was based on the dictionary of the Esseker dialect (Petrović, 2020), on Theo Binder's doctoral thesis (Binder, 2006) and partially on the master thesis on Germans and the German language in Slavonia (Vincetić, 2010)
} 


\section{International Conference on Research in}

\section{BEHAVIORAL \& SOCIAL SCIENCES}

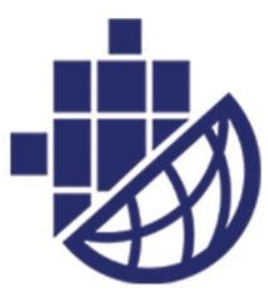

July $23-25,2021$

Stockholm, Sweden

Vocabulary: borrowings are bi-directional: Croatian words included into the vocabulary (along with words from other languages) receive German affixes, and some German words are taken up into the Croatian language and behave as Croatian words, e.g. with Croatian infinitive endings or Croatian gender forms (e.g. fajhtati veš - German: die Wäsche feuchten $=$ moisten the laundry).

Endings: the suffix -er is always pronounced as [a]

Mixed Compounds: a specific type of compounds typical for the Esseker dialect are compounds using words from different languages. Such compounds are usually very interesting and amusing. However, although they may sound funny or as a joke, they refer to actual objects or persons: e.g. dudapam (Croatian: dud(a) $=$ mulberry + German: der Baum $=$ dudapam i.e. mulberry tree; gačahouzn (Croatian: gaće $=$ men's underwear + German: die Hose $=$ trousers $=$ gačahouzn i.e. long johns); šịacnjega (German: der Schürzenjäger

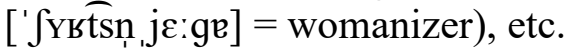

Typical compounds referring to women include the woman's name or profession and the Hungarian word neni: Martaneni = a woman named Marta (aunt or Mrs. Marta); rodaneni $=\mathrm{a}$ midwife (from roda $=$ stork, so it would actually mean Mrs. Stork $/$ the woman that brings/delivers babies). Equally, compounds for men use the Hungarian word bači (uncle or mister), e.g Martinbači = uncle/Mr. Martin, but they would mostly be used with names and rarely with professions (e.g. šnajdabači = tailor).

Plurals: the plurals are simply made by adding the German Ending $-\mathrm{n}$ (sometimes $-\mathrm{en}$ ) to all nouns

There are various other characteristics relating to the word order in different types of sentences, to the lack of the Genitive case and its replacement with the preposition von + Dative, or to the position of Prepositions in interrogative sentences. The written form of the Esseker dialect is, as it was already indicated, a topic of its own since the words are actually written as they are pronounced. This means that two or more words are sometimes written as one. Finally, we must not forget the probably greatest problem with the Esseker dialect - the intonation. It differs from the usual intonation in Croatian but does not follow German intonation rules either. In fact, it uses specific combinations of usual intonation patterns, which were described by Theo Binder in his doctoral thesis (Binder, 2006). Each of the characteristics that were only mentioned here deserves special attention and thorough studies.

\subsection{Methods}

The methods applied in the paper are the primary sources analysis (of applicable legislation, statistical demographic and historical data), critical discourse analysis, and interpretation of relevant LPP theories providing a framework for the language policy and multilingualism in the city of Osijek in the 19th century. Specifically, the following sources have been analysed for establishing the top down language policy in the Habsburg Monarchy: The Pillersdorf Constitution (Pillersdorfsche Verfassung vom 25 April 1848), the 31. 


\title{
8 International Conference on Research in
}

\section{BEHAVIORAL \& SOCIAL SCIENCES}

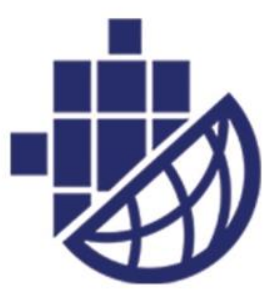

July $23-25,2021$

\author{
Stockholm, Sweden
}

Imperial Ordinance 5 of 7 December $1849^{6}$ published in the Official Gazette of the Austrian Empire p. 59, the 150. Regulation of the Ministry of Culture and Education of 8 August 1859, published and sent on 20 August 1859 and amending the Ordinance no 315 (published in Official Gazette on 9 December 1854). The 150. Regulation was published in the Official Gazette of the Austrian Empire in 1859 p.4477, the Croatian-Hungarian settlement of 1868 (Articles 57-60), Article 19 of the Constitution of 21 December 1867

The analysis and comparison of statistical data issued by the Croatian Institute of Statistics, the State Archives in Osijek are applied as methods for establishing the population composition as regards the number of nationalities members speaking different languages in the 19th century Osijek. The paper refers to the census of 1857 and 1890 . The data analysis results are indicative and descriptive for drawing conclusions on the topic.

\subsection{Results and discussion}

According to the statistical data published by the Croatian Institute of Statistics ${ }^{8}$ in 1857 , the city of Osijek had 20,858 inhabitants of different nationalities speaking different languages. There were 10,020 Croats and Serbs, 3,272 Germans, 438 Hungarians, 36 Italians and 588 persons of other nationalities. However, the data for the 1890 census show following changes in the Osijek population: 10,657 Germans, 5,516 Croats, 1,602 Serbs and 1,378 Hungarians (Plevnik 1987: 87 in Petrović 1998:167). This high increase in the number of the German population in Osijek was caused by economic growth of the city and speaks for the position and role of the German population in economic, cultural and social development of the city. The number of German speaking population relates to the general number of German speakers in Croatia. The data on the number of native speakers of different languages in the population of Croatia show that there were 1,712,353 Croatian or Serbian speakers and 83,139 German speakers in 1880 whereas in 1890 there were 1,921,719 Croatian or Serbian speakers and 117,493 German speakers. ${ }^{9}$

The 19th century Habsburg Empire was a multicultural environment in which numerous nationalities had to adapt to frequently altered language policies. As part of such diverse environment, the city of Osijek stands out as an evidence of a successful multicultural cohabitation.

The Habsburg language policy (including legislation that governs the languages in education) was centralised (top down approach) and it is worth researching into manifestations of language diversity at the level of everyday practices. In this regard, the paper deals with language policies in administration and education in Osijek based on general legislative framework for the Habsburg Monarchy. It focuses on a selection of applicable

\footnotetext{
5 "Kaiserliche Verordnung Croatian: carska naredba, Erlass des Justizministeriums, Croatian: naredba (prikaz) ministerstva pravosudja"

${ }^{6}$ ALEX Project data, retrieved from https://alex.onb.ac.at/alex.htm on 19 May 2021. In Croatian: Sveobći deržavo-zakonski i vladni list za Carevinu Austriansku. Komad I. Izdan i rasposlan na 1. studenoga 1849.

${ }^{7}$ Ibid.

${ }^{8}$ Croatian Institute of Statistics https://www.dzs.hr/; accessed on 20 May 2021.

9 According to the Statistical Atlas of the Kingdom of Croatia and Slavonia 1875-1915 (Signjar 1915:8 in Sočanac 2012:301).
} 


\title{
8 International Conference on Research in
}

\section{BEHAVIORAL \& SOCIAL SCIENCES}

\author{
July $23-25,2021$
}

\author{
Stockholm, Sweden
}

legislation governing this issue. The Habsburg rulers had to have a reliable and authentic legal terminology for the entire Empire. In this regard as soon as the Stadion Constitution of 4 March 1849 established the principle of equal treatment, the official/legal gazette (the Reichsgesetzblatt) was introduced by the imperial patent. In the Preamble to the patent the principle of the Monarchy unity, the equal treatment of the nations of the Monarchy, and the equality of all citizens before the law were introduced. The Gazette should have ten editions in ten languages of the Monarchy (landesübliche Sprachen) ${ }^{10}$ : 1. German, 2. Italian, 3. Hungarian, 4. Bohemian (the Moravian and Slovakian written language), 5. Polish, 6. Ruthenian, 7. Slovenian (the Windish and Carniolan written language), 8. The SerbianIllyrian language using Serbian Cyrillic script, 9. The Serbian-Illyrian language using Latin script, 10. Romanic (Moldovan-Wallachian language). ${ }^{11}$ The basic idea of linguistic equality in the Habsburg Monarchy was reflected in all constitutional documents at national level, in the Pillersdorf Constitution (Pillersdorfsche Verfassung vom 25 April 1848) ${ }^{12}$ as well as in the draft constitution of the Reichstag of Kremsier and in that of Francis Joseph I passed on April 4 March 1849. According to Haslinger $(2007: 98)^{13}$ the state extended the principle of equality for the first time to languages that had previously been used in the administration of particular regions but had no rights - such as Serbian and Croatian in Dalmatia or Ukrainian in Galicia. For these languages, it meant upgrading the terminology deficits that were still present and that had to be compensated for. Pursuant to $\S 4$ all ethnic groups are granted their national integrity and national languages. However, the situation in practice was completely the opposite. ${ }^{14}$

Introduction to the General Official Gazette for the Austrian Empire ${ }^{15}$ (of 27 November 1848) comprises the patent of the Emperor Francis Joseph I ordering that at the initiation of the Ministry Council pursuant to $\S 1$, the Official Gazette is to be published in all languages commonly spoken in the Empire i.e. upon the Official Gazette publishing in Vienna. The purpose of the Gazette was better understanding of the laws, decisions, regulations and orders. All versions of the Gazette were considered equally valid (authentic). ${ }^{16}$ Those that are not published in German shall be amended with a German translation. $\S 2$ of the Introduction

10 According to Kann (1964) the term Landessprache (language of a land) in Article 19 referred to a language used by at least 20 per cent of the population of a crownland (as recognized nationalities) whereas landesübliche Sprache (language in common use in a land) meant the language used to communicate with the authorities, in the schoolroom and for cultural events.

${ }^{11}$ Reichsgesetzblatt (RGB1. 153/1849, Einleitung I, VI).

${ }^{12}$ The Pillersdorf Constitution as a whole never applied in practice. Pillersdorfsche Verfassung, Allerhöchstes Patent vom 25. April 1848, Verfassungs-Urkunde des österreichischen Kaiserstaates. Retrieved from https://www.jku.at/fileadmin/gruppen/142/pillersdorfsche_Verfassung.pdf (15 March 2021)

${ }^{13}$ Haslinger, P. (2008) Sprachenpolitik, Sprachendynamik und imperiale Herrschaft in der Habsburgermonarchie 1740-1914, Zeitschrift für Ostmitteleuropa-Forschung, 57(1), Herder Institut, retrieved from https://www.zfo-online.de/portal/index.php/zfo/article/view/8799/8798 (15 March 2021).

14 "§4 Allen Volksstämmen ist die Unverletzlichkeit ihrer Nationalität und Sprache gewährleistet." Retrieved from: https://www.jku.at/fileadmin/gruppen/142/pillersdorfsche_Verfassung.pdf (15. March 2021)

15 The Croatian equivalent: "Sveobći deržavo-zakonski i vladni list za Carevinu Austriansku"

${ }^{16}$ Due to high publishing costs, this criterion of authentic versions in ten languages was maintained until 1853 when the German text was again the only valid version. The Gazette translations into other 10 languages appeared in the local gazettes. 


\section{International Conference on Research in}

\section{BEHAVIORAL \& SOCIAL SCIENCES}

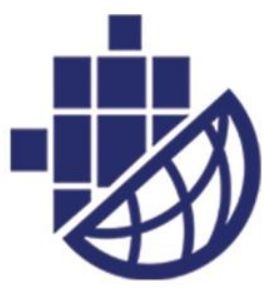

July $23-25,2021$

Stockholm, Sweden

lists the types of legal texts published in all languages spoken commonly in the Empire. $\S 4$ stipulates that one official gazette shall be published in every crownland (krunovina) in the languages of that crownland with attached German translation. In $\S 8$ it is set out that the Official Gazette shall be distributed to all authorities without charge for all lands and all land authorities whereas pursuant to $\$ 9$ the districts are obliged to have the Gazette in the languages spoken in the districts. The Introduction of the Official Gazette (pp. V-VII) states that the Gazette shall be published by the Imperial and State Publishing House in Vienna in all languages of the crownlands. The first edition shall contain the German text on both pages, from the second edition every edition shall include the crownland language text on the left page and the German text on the right page. ${ }^{17}$

The 32. Decision of the Ministry of Finance of 9 December 1849 (p.59) is the Royal Ordinance/Regulation of 7 December 1849 valid throughout the Empire that amends the provisions of the Patent of 4 March 1849 governing the publications of Empire general acts and official gazette in all 10 native languages of the Empire. It sets out the amendment of the rule that the passed laws must be immediately published in ten languages of the Empire so that these are published in only one language or several languages out of ten languages of the Empire and only later in all other languages of the Empire.

Official Gazette of the Austrian Empire, 1859, p.447, published and sent on 20 August $1859^{18}$ comprises the 150. Regulation of the Ministry of Culture and Education of 8 August 1859 amending the Provision no 315 published in Official Gazette on 9 December 1854 on the usage of the German language in teaching and education in all grammar schools of the Empire, excluding the grammar schools in Lombardy-Venice. The Emperor decided on 20 July 1859 that in higher grades of grammar schools in the regions where the majority of population speaks other languages than German, the language of teaching and conversation had to be German, in addition to the obligatory German language teaching classes, so that the pupils after completing the grammar schools could speak and write German well.

Due to its linguistic diversity, the Habsburg Monarchy had an elaborate system of central and provincial laws. The basis for the laws of diverse nationalities was the Constitution of 21 December 1867. Pursuant to Article 19, all ethnic groups are equal and have right to use their languages. The languages common in a region are equal and the ethnic groups are entitled to exercise this right in education, administration and in public domain, as well. On the other hand, in the regions with various ethnic groups, the public education shall guarantee each group the right to receive education in their own languages and the members of the ethnic groups are not forced to learn the second regional language. ${ }^{19}$

Articles 57-60 of the Croatian-Hungarian settlement of 1868 govern the usage of Croatian language in the Kingdom of Dalmatia, Croatia and Slavonia. Pursuant to $\S 57$, the Croatian

17 The types of legislative texts comprise as follows: “a) all state and regional laws, b) all imperial regulations and orders that shall be published for the whole state or particular crownlands, c) orders published by the ministries in their jurisdictions for the law enforcement, regardless of the fact that they are generally binding in the whole state or only in some of its parts." Alex Project data, retrieved from https://alex.onb.ac.at/alex.htm (19 May 2021).

${ }^{18}$ Reichsgesetzblatt in Alex Project; retrieved from https://alex.onb.ac.at/alex.htm (19 May 2021).

${ }^{19}$ Reichsgesetzblatt (RGB1, 142/867) (Ibid.) 


\title{
8 International Conference on Research in
}

\section{BEHAVIORAL \& SOCIAL SCIENCES}

July $23-25,2021$

\author{
Stockholm, Sweden
}

language is established as an official language for the bodies of the joint government. Pursuant to $\S 58$, the Croatian language is the language of writs and decisions. $\S 59$ sets out that Croatian is established as the language of the legislation, autonomous government and assembly. Pursuant to $\S 60$ the laws passed by the Emperor and the King shall be issued in the Croatian language for the Kingdoms of Dalmatia, Croatia and Slavonia.

\section{Conclusion}

The results of the legal discourse analyses and comparisons show that institutional language policy and language practices in the $19^{\text {th }}$ century Osijek are reflected in literary and vernacular multilingualism contributing to the hybrid linguistic identity of the city. This, however, may also be regarded as an evidence of assimilation in a multinational and multicultural environment. In the $19^{\text {th }}$ century Osijek, five languages were used in official and/or private domains (Latin, German, Hungarian, Croatian and Serbian). Latin was until 1847 the obligatory language in politics and administration and until 1850 the language of instruction in grammar schools. In the $19^{\text {th }}$ century, intensive efforts were made to introduce Hungarian as the official language in civil Slavonia. In the first four classes of grammar school, Croatian was the language of instruction, but German and Latin could be learnt at this level as foreign languages as well. German was introduced as the language of instruction in Croatian grammar schools in 1854 (Novak, Štebih Golub; 2015:131).

This multilingual pattern was supported both by top down language policy (in education and administration) and the unique vernacular (the Esseker German) affecting the multilingual landscape of the city. The German language vocabulary has been used in the everyday communication among Croatian-speaking citizens of Osijek up to present days although since 1868 Croatian has been the language of administration and education. There was a significant number of native speakers of German in Osijek until 1918 and even later and the census of 1910 showed that there were still $37.81 \%$ native speakers of German although Croatian native speakers formed the majority (39.18\%) for the first time.

The narrative based on close reading of documents governing language diversity in the Habsburg Empire provides insight into the $19^{\text {th }}$ century multilingual city of Osijek and evidence of language diversity management in the late Habsburg Empire. The Esseker German dialect is an evidence of unique multilingual practices in the city of Osijek at that time. In this regard, language policy (legislation governing language use in education, administration) was centralized at state level in form of imperial patents whereas language diversity (including the Esseker German dialect) manifested itself and was practiced at the everyday, local level. The existence of the Esseker German dialect in practice speaks for the fact that multilingual societies are not necessarily conflict-prone. Finally, the paper makes space for further research to be conducted into the strategies that inhabitants of Osijek had to employ to successfully interact in multilingual private and public domains. 


\section{$8^{\text {th }}$ International Conference on Research in}

\section{BEHAVIORAL \& SOCIAL SCIENCES}

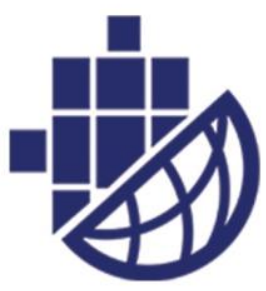

July $23-25,2021$

Stockholm, Sweden

\section{References}

Bilić-Meštrić, K. (2014). Jezična raznolikost i jezične politike grada Osijeka. Doktorski rad. Sveučilište Josipa Jurja Strossmayera u Osijeku. Filozofski fakultet. Osijek

Binder, T. (2006). Njemačke posuđenice u hrvatskom govoru Osijeka. Preveo i za tisak priredio Velimir Petrović. FF Press. Zagreb.

Burić, V. Prvi pokušaji književnog i kulturnog udruživanja u Osijeku 1841. "Jeka od Osijeka! i književno društvo 1843. "Narodna čitaonica", Radovi Centra za znanstveni rad Vinkovci 3, Zagreb 1975, (297-323).

Johnson D.C. (2013) What is language policy?. In: Language Policy. Research and Practice in

Applied Linguistics. Palgrave Macmillan, London. https://doi.org/10.1057/9781137316202_1

Kaplan, R. B., and Baldauf, R. B. (1997). Language planning from practice to theory. Clevedon England: Multilingual Matters.

Kann, R. (1964) Das Nationalitätenproblem der Habsburgermonarchie. Geschichte und Ideengehalt der nationalen Bestrebungen vom Vormärz bis zur Auflösung des Reiches im Jahre 1918. Vol. 1: Das Reich und die Völker. Graz: Hermann Böhlaus Nachfolger.

Kolenić, Lj. (2009). Hrvatski književni jezik u Osijeku od 1809. godine do 2009. godine. Anali zavoda za znanstveni $i$ umjetnički rad u Osijeku, sv. 25, 71-86.

Kordić, Lj. (2013). Višejezičnost kao odrednica prošlosti i imperativ budućnosti: primjer grada Osijeka. In: L. Sočanac, Lingvistički i pravni aspekti višejezičnosti (53-77). Zagreb: Nakladni zavod Globus.

Lo Bianco, J. (2010). Language Policy and Planning. In N. H. Hornberger and S. L.McKay (eds.), Sociolinguistics and language education (143-176). Clevedon, GBR: Multilingual Matters.

Mažuran, I. (1993). Stanovništvo i vlastelinstva u Slavoniji 1736. godine i njihova ekonomska podloga: Stanovništvo $i$ vlastelinstva u Slavoniji 1736. godine $i$ njihova ekonomska podloga. Radovi Centra za znanstveni rad u Osijeku. Downloaded from Mazuran Ive $\underline{\text { Stanovnistvo I Vlastelinstva U Slavoniji } 1736 \text { (scribd.com) }}$

Mažuran, I. (1994). Prostorna i strateška važnost sjevernoistočne Hrvatske. In: S. Sršan, Hrvatska-Povijest sjevernoistočnog područja (40-51). Povijesni arhiv u Osijeku, Osijek.

Njari, D. (2010). Povijesni razvoj naselja Retfale. Essehist, 2 (2), 74-76. Downloaded from https://hrcak.srce.hr/63802

Novak, K.; Štebih Golub, B. (2015). Deutsch im Diskurs der Illyrischen Bewegung (18351843): Bedrohung, Leitbild, Überbrückungsinstrument. In: Zagreber germanistische 


\section{$8^{\text {th }}$ International Conference on Research in}

\section{BEHAVIORAL \& SOCIAL SCIENCES}

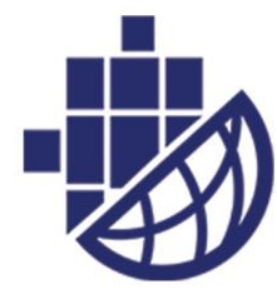

July 23-25,2021

Stockholm, Sweden

Beiträge

$24 / 2015$

$(127-148)$.

Downloaded

from

https://zgbde.files.wordpress.com/2019/08/zgb-24-2015-book-za-web.pdf (23.5.2021)

Obad, V. (1989). Slavonska književnost na njemačkom jeziku. Osijek: Radničko sveučilište Božidar Maslarić.

Obad, V. (1994). Srednjoeuropska književnost slavonske provenijencije. In: S. Sršan, Hrvatska-Povijest sjevernoistočnog područja (248-256). Povijesni arhiv u Osijeku, Osijek.

Petrović, V. (1998). Zu den Merkmalen des Essekerischen. Über Grenzen hinweg. In: Universitäten Augsburg und Osijek: Zwanzig Jahre Partnerschaft. Unatoč svim granicama. (167-184). In: Sveučilišta Augsburg i Osijek: Dvadeset godina partnerstva. Augsburg: Wißner.

Petrović, V. ed. (2001). Essekerisch - Das Osijeker Deutsch. Wien: Edition Praesens in Zusammenarbeit mit dem Institut für deutsche Kultur und Geschichte Südosteuropas München.

Petrović, V. ed. (2011). Esekerski tekstovi - Essekerische Texte. Sakupio i preveo Gesammelt und übersetzt von Velimir Petrović. DG Njemačka zajednica, Zemaljska udruga Podunavskih Švaba u Hrvatskoj, Osijek.

Petrović, V. (2020) Esekerski rječnik. Essekerisches Wörterbuch (2nd ed).FF Press. Zagreb.

Plein, L. (2002). Die Essekerische Sprechart. Gesammelte Gespräche aus Osijeker Gassen und Peripherie. Reprint. Savez Nijemaca i Austrijanaca Hrvatske - centrala Osijek.

Riehl, C. M. (2013). Sprachkontaktforschung. Eine Einführung. Tübingen: Gunter Narr Verlag.

Romaine, S. (2003). Multilingualism. In: Mark Aronoff and Janie Rees-Miller, The Handbook

of Linguistics, Blackwell Publishers: Oxford.

Sočanac, L. (2012). Language policies in Croatia in a diachronic perspective. Jezikoslovlje, 13 (2), (299-325). Downloaded from https://hrcak.srce.hr/91460.

Sršan, S. (1994). Školstvo u sjevernoistočnoj Hrvatskoj. In S. Sršan, Hrvatska-Povijest sjevernoistočnog područja (207-221). Osijek: Povijesni arhiv u Osijeku.

Sršan, S. (1996). Povijest Osijeka - sažeti pregled, Povijesni arhiv u Osijeku.

Sršan, S. (1997). Osamstota obljetnica Osijeka. Zbornik Muzeja Đakovštine, 4 (1), 5-16. Downloaded from https://hrcak.srce.hr/236657.

Sršan, S. (2000). Naselja u istočnoj Hrvatskoj krajem 17. i početkom 18. stoljeća. Državni arhiv u Osijeku. Osijek. 


\section{International Conference on Research in \\ BEHAVIORAL \& SOCIAL SCIENCES}

July 23-25,2021

Stockholm, Sweden

Schiffman, H. F. (1996). Linguistic Culture and Language Policy. London: Routledge

Vincetić, M. (2010). Volksdeutsche und die deutsche Sprache von 1914 bis 1945 in Slawonien - Diplomarbeit. Universität Wien.

Vukelich, W. von (1992). Spuren der Vergangenheit. Erinnerungen aus einer K.u.K. Provinz, Osijek um die Jahrhundertwende. Obad, V. ed. München: Süddeutsches Kulturwerk. 